\title{
The Implementation of Hypnoteaching Method in Increasing Motivation to Learn English for Senior High School in Pekanbaru
}

\author{
Ardiya $^{1}$, Wandi Syahfutra ${ }^{2}$ \\ ${ }^{1}$ Universitas Muhammadiyah Riau, Pekanbaru, Indonesia \\ 1email: ardiya@umri.ac.id \\ ${ }^{2}$ Universitas Muhammadiyah Riau, Pekanbaru, Indonesia \\ 2 email: wandisyahfutra@umri.ac.id
}

\begin{abstract}
:
This study explores hypnoteaching method to increase students' senior high school Pekanbaru motivation in learning English. Using a quantitative approach with a quasiexperimental design and provide pre-test and post-test to the both control class groups and experimental groups where SMA Handayani students and SMA PGRI students as research subject. The findings showed that 1) low student motivation is one of the causes of low student learning outcomes, 2) a classroom atmosphere to support the learning process is not built yet, 3) teachers do not found yet the right method to increase and keep students learning motivation. Based on the results of the research data processed using the pairedsample $\mathrm{t}$ test, there were found significant differences, namely before and after implementing the hypnoteaching method in learning English with alpha results less than 0.05. This study is beneficial in enriching literature in the scope of English education study programs, especially in Indonesia and others adopting English as a foreign language as a matter of applying appropriate and a more effective learning methods.
\end{abstract}

Keywords: Hypnoteaching Method, Motivation, English Learning.

\section{INTRODUCTION}

Education is a planned effort to create an atmosphere of learning and the learning process so that the students can actively develop their potential. Through education, a person can acquire intelligence, knowledge, personality, skills, and habits. Education can be obtained in various ways, especially today. We can do various ways to get education both in terms of location and source.

School is one of the places for teaching and learning activities. In this case the school was established to be able to develop learning motivation both from within and from the environment. Motivation in learning is very important because motivation can improve student learning outcomes. High motivation can encourage students to excel both at school and outside of school.

Motivation is one of the factors that can influence the learning process and success in learning. Motivation consists of two, namely intrinsic and extrinsic motivation. Intrinsic motivation is 
motivation that comes from within the students themselves. Meanwhile, extrinsic motivation is motivation that comes from outside the student which functions as a driving force that can make a person very excited in learning. We can see real evidence from students who have positive motivation. The student seems to have interest, concern and hard work so that all the assignments given by the teacher can be completed properly.

Based on the observations that have been provided, the motivation of high school students in Pekanbaru during the learning process is still lacking. At the beginning of the learning process they were seen to be enthusiastic, but in the middle until the end of the learning process their motivation decreased. In addition, the atmosphere in the classroom seemed less supportive of the learning process. The environment also causes student motivation to decrease. Therefore, it is considered important to implement a method to maintain and increase the motivation to learn English for high school students in Pekanbaru.

One of good methods to apply is the hypnoteaching method. According to Nurcahyo in Hajar (2011), literally, hypnoteaching comes from the words hypnosis and teaching. Hypnosis is a condition of relaxation, focus, or concentration, which characterizes this condition, is that the human sensory sensors are much more active. Meanwhile teaching is teaching. Under hypnosis, a person can easily absorb information precisely without anxiety. Therefore, this hypnosis condition can be utilized in the teaching and learning process so that the learning outcomes can be achieved optimally.
The science of hypnosis has been used in all areas of life, for example, health, psychology, entertainment and education. In the field of education, we recognize hypnoteaching. According to Novian Triwidia jaya in Yustisia (2012), hypnoteaching is a combination of teaching that involves the conscious and subconscious mind. Hypnoteaching is a creative, unique, and imaginative learning method and in its application, the science of hypnosis is used.

Based on the background above, the research on "The Implementation of Hypnoteaching Method to Increase Students' Motivation in Senior High School Pekanbaru in Learning English" is believed to be able to increase and maintain motivation in learning so that learning outcomes can be achieved optimally.

Before doing a discussion about hypnoteaching, it is better to explain about hypnosis. In the NLP (Neurology Linguistic Programming) educational hypnosis web, it is stated that hypnosis has been used in prehistoric times. This can be proven by the discovery of pictographs and ancient writings. Along with the times, hypnosis has developed in almost all fields, including education.

In the field of education, hypnosis can be applied to improve student learning outcomes in learning. Through hypnosis, teachers or students can improve memory, focus and creativity. Of course, these three components play an important role in achieving learning goals. Through memory, focus and creativity, what the teacher or student hopes can be achieved. Hypnotherapy in education is known as hypnoteaching. 
Hypnoteaching is a combination of two words, namely hypnosis and teaching. Almatin explained, that hypnosis is a state in which the conscious mind can penetrate so that ideas or thoughts can be accepted, which can lead to behavioral changes in the emotional mental order. Meanwhile teaching means teaching. Gunawan argues that hypnoteaching is defined as a combination of teaching that involves a conscious mind and a subconscious mind.

Meanwhile Hajar (2011) explains that hypnoteaching is the art of communicating teachers by giving suggestions so that it can produce smart students. By giving suggestions, students can concentrate on a certain situation. It is beneficial to the information in any form conveyed by the teacher can be received and stored in students' memories.

As the application of hypnosis science, actually in hypnoteaching does not make students fall asleep in class, but they have been conditioned to learn. So, they are ready to follow and receive subjects. This can be implemented, if the teacher is in a stable state both psychologically and psychologically, and the teacher is ready to teach students without any doubts.

According to M. Noer (2010) there are six things that teachers must pay attention to in implementing hypnoteaching, namely, teacher appearance, sympathy, empathetic attitude, use of language, motivation of children with stories / stories, display and master the hearts of students. It is impossible the teachers can achieve the goals they want to achieve through hypnoteaching without these six things.
In addition, Novian (2010: 41) explains that a number of hypnoteaching steps must be taken in school by teachers including Yelling, Emotion clock, Teach and praise, and Magic question.

Yelling means shouting, this is useful to the students to be concentrated on the subject. This can be implemented by shouting together. The shouting procedure must be agreed upon before the beginning of the lesson so that students can follow it and the teacher can easily manage the students.

Emotion clock means the clock that regulates emotions. Each person's emotions are different every minute and second, as well as students. Therefore, we need a way to regulate how they still have emotions at the same time. The emotional clock is divided into 4 parts, including: quiet hour, discussion hour, release time, and button clock. The five emotional clocks are marked with different colors, so that students know when the teacher displays the color and students have to do activities according to the time shown by the teacher. To facilitate this activity, the teacher can be assisted by the class leader to explain the emotional clock to his classmates.

Teach and praise means in the learning process, $90 \%$ of students are able to remember what they saw, heard, and said. Therefore, the teacher must do a way so that students are able to reach $90 \%$ by teaching each other the material to other friends, so that their friends understand the material being taught. Furthermore, the teacher gives praise to students because by giving praise the students feel happy and confident because they can understand the material that has been given by the teacher. 
Magic question means the questions in question are questions that can make students excited and motivated to answer questions given by the teacher. These questions can build a learning process, provide solutions, increase potential and lead students.

Hypnoteaching is a creative, unique and imaginative learning method. The learning process becomes fun for students, because the teacher uses positive language to make students comfort for the lesson. This shows a good interaction between teacher and students. The learning process looks dynamic and active.

After discussing the theory of hypnoteaching, a theoretical review of motivation is described next. Motivation is an impetus in a person to do something in order to achieve the desired goal. This is in line with Sardiman (2014) which states that motivation is "a change in energy in a person's energy which is marked by the emergence of" feelings "and is preceded by a response to a goal". So it can be concluded that motivation is an encouragement that is owned by a person to achieve a goal by doing an act, whether intentionally or unintentionally.

Motivation and learning are two things that are interrelated and influence each other. Learning itself is a change in behavior based on goals to achieve certain goals. According to Uno (2016) motivation can arise because of intrinsic factors, in the form of desire and desire to succeed and encouragement of learning needs, expectations of ideals. Meanwhile, the extrinsic factors are reward, a comfort learning environment, and interesting learning activities.
The role of motivation in teaching and learning activities is very important, because without motivation teaching and learning activities will be disrupted and of course affects learning outcomes. Many things can be achieved if students have good motivation, including: can develop activities and initiatives, can maintain persistence in learning. Sardiman (2014) states that there are several forms and ways of growing motivation, namely: giving numbers, gifts, competence, Egoinvolvement, giving tests, giving praise, giving results, expected goals.

Wina Dwi Puspita Sari (2018) has examined the implementation of the hypnoteaching method on student learning outcomes, the results show that the application of the hypnoteaching method has succeeded in improving student learning outcomes. Meanwhile, Bahar Agus Setiawan (2018) also examined the effect of the hypnoteaching method on student activity and learning outcomes and the results concluded that the hypnoteaching method could improve student activity and learning outcomes. Muhammad Zuhri Dj and Sukarnianti (2015) conducted research on the use of hypnoteaching to improve students 'writing skills and the results showed that students' writing skills improved after using the hypnoteaching method. Furthermore, Muhammad Zuhri Dj and Sukarnianti (2015) conducted research on the use of hypnoteaching to improve students 'writing skills and the results showed that students' writing skills improved after using the hypnoteaching method. 


\section{METHOD}

This study was designed to implement the hypnoteaching method to increase students' motivation to learn English by using a quantitative approach.

According to Creswell [10], quantitative research is an approach to testing objective theory by examining the relationship between variables. Basically, these variables can be measured using instruments or tests, so that numbered data can be analyzed using statistical procedures. This study used a quasi-experimental nonequivalent control group design. This study consisted of two classes, namely the experimental class and the control class. The experimental class was treated using the hypnoteaching method, while the controlled class was treated using conventional methods. The samples in this study were SMA Handayani Pekanbaru and SMA PGRI students.

While the variables of this study are the independent variable and the dependent variable: the independent variable $(\mathrm{X})$ is the hypnoteaching method and the dependent variable $(\mathrm{Y})$ is student motivation. The types of this research can be seen in the table below:

\begin{tabular}{cccc}
\hline E & K1 & X & K2 \\
C & K3 & X & K4 \\
\hline
\end{tabular}

Information:

E : Experiment Class

C : Control Class

K1 : Pre-test (in the experiment class)

K2 : Pre-test (in the experiment class)

$X$ : Treatment using the hypnoteaching method

K3 : Post-test (in the experiment class)
K4 : Post-test (in the control class)

The instruments of this study were test and questionnaires. This is supported by Sugiyono [11] who stated that the data research instruments in quantitative research can be done by interview, questionnaire and observation.

The second data collection instrument was a questionnaire containing the application of the hypnoteaching method in increasing students' motivation to learn English. After the data is obtained through interviews and interviews, the data will be processed quantitatively. The data were obtained from the pre-test and post-test. Then the researcher carried out the steps of the procedure including finding the average of students' answers using the average formula, looking for the average student answers from the questionnaire using a Likert scale, as shown in the table below:

Table 1. Likert Scale

\begin{tabular}{ccc}
\hline $\begin{array}{c}\text { Positive } \\
\text { statement }\end{array}$ & Statement & $\begin{array}{c}\text { Negative } \\
\text { statement }\end{array}$ \\
\hline 5 & $\begin{array}{c}\text { Strongly } \\
\text { agree }\end{array}$ & 1 \\
\hline 4 & Agree & 2 \\
\hline 3 & Not know & 3 \\
\hline 2 & $\begin{array}{c}\text { Strongly } \\
\text { disagree }\end{array}$ & 4 \\
\hline 1 & Disagree & 5 \\
\hline
\end{tabular}

The scale consists of 11 positive statements and 14 negative statements. Negative statements are $1,2,5,7,11,14$, $18,19,22$ and 23. While positive statements are $3,4,6,8,9,10,11,12,13$, 15, 16, $17,20,21,24$ and 25. The maximum score is 100 and the minimum score is 25. After the test, the standard deviation and differences between the pre- 
test and post-test are looked for by applying the hypnoteaching method using a formula.

Data analysis in quantitative research is described as a reflection, reaction and process of interaction between researchers and decontextual data that has interpretations in social gatherings. Decontextual data is what the researcher chooses, whether to present key points related to the research question, or to repeat the entire interview.

In addition, the data analysis in this study used a pairwise difference test. To achieve the objectives in this study, the method used is the Paired Sample T-Test and / or Wilcoxon Signed Test analysis model depending on the data distribution, the analysis was carried out using SPSS 16.0 software. Previously, the collected data would be analyzed in stages by first performing a statistical test with a normal distribution test using the KolmogorovSmirnov test. Then, the partial hypothesis testing is carried out using the Paired Sample T-Test analysis test if the data is normally distributed and the Wilcoxon Signed Rank analysis test model if the data is not normally distributed. For the level of significance or the alpha value $(\alpha)$, according to Ghozali (2002), the commonly used alpha values are 0.05 and 0.01 , in this study the significance level for all tests was set at 0.05 or $(5 \%)$.

\section{FINDINGS AND DISCUSSION}

\section{Descriptive Statistics Test Results}

Data descriptions are used to provide an overview of the data that has been obtained. This general description can be a reference to see the characteristics of the data we get. Descriptive statistics are more concerned with collecting and summarizing data, as well as presenting the summary results. The following will present the data that will be used in the research and which have been processed using descriptive analysis techniques:

Table 2. The Result of Descriptive Statistics

\begin{tabular}{|lccccc|}
\hline \multicolumn{7}{|l|}{ Descriptive Statistics } \\
\hline \multicolumn{1}{|c|}{ N } & Min & Max & Mean & $\begin{array}{c}\text { Std. } \\
\text { Deviation }\end{array}$ \\
\hline PreTest & 61 & 16 & 68 & 46.36 & 12.907 \\
PostTest & 61 & 44 & 88 & 69.57 & 7.422 \\
Valid N & 61 & & & & \\
(listwise) & & & & & \\
\hline
\end{tabular}

Sources: Statistic Data SPSS, 2020

Table 2 shows that a number of 61 respondent data were sampled for the hypnoteaching method experiment. A number of 61 respondents participated in the pre-test and post-test before the hypnoteaching method experiment.

From the results of the pre-test score assessment, the lowest score was 16 while the highest score was 68. Meanwhile, from the results of the post-test score assessment, the lowest score was 44 while the highest score was 88. When viewed from the average value, the difference between the mean score of pre-test and post-test is 23.21 .

\section{Normality Test Result}

Normality test is used to measure whether the data has a normal distribution or not. In this case the data normality test was carried out using the KolmogorovSmirnov approach. The KolmogorovSmirnov test is a nonparametric statistical test that is used to determine the distribution of data used in research with normal distribution or not. The test results of the Kolmogorov Smirnov test are as follows: 
Table 3. Normality Test Result

One-Sample Kolmogorov-Smirnov Test

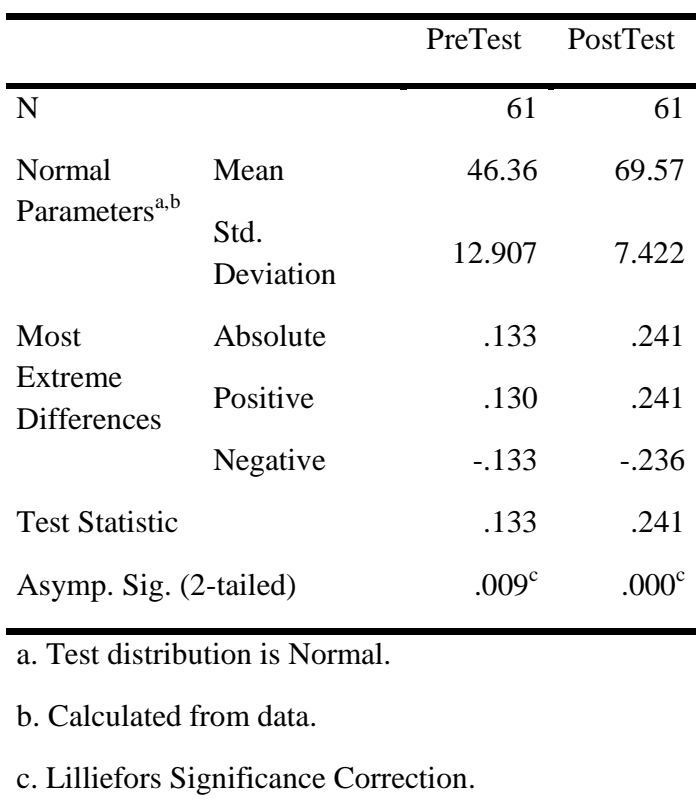

Source: Statistic data SPSS, 2020

Based on Table 3, it can be concluded that the Pre-Test variable data is not normally distributed because of the Asymp value. Sig (2-tailed) of 0.009 is smaller than 0.05 so that the data is not normally distributed. Likewise, the Post-Test variable data has an Asymp value. Sig (2-tailed) of 0,000 is smaller than 0.05 so that the data is not normally distributed. Because the data is not normally distributed, the statistical test used to compare the Pre-Test and PostTest is a non-parametric statistical paired difference test. In SPSS this test can be done using the Wilcoxon Signed Rank Test.

\section{Hypothesis Test Result}

To test whether there was a difference between the pre-test and post-test scores in the interrelated observation group, the Wilcoxon Signed Rank Test was used. The Wilcoxon Signed Rank Test is a nonparametric test. The hypotheses to be tested are:
$\mathrm{H} 0=\rho>0.05$. There was no significant difference in scores before and after the hypnoteaching method implemented.

Ha $=\rho \leq 0.05$ There was a significant difference in scores before and after the hypnoteaching method implemented.

Following are the results of the Wilcoxon Signed Rank Test with SPSS 16:

Table 4. Hypothesis Test Result

Test Statistics ${ }^{\mathrm{a}}$

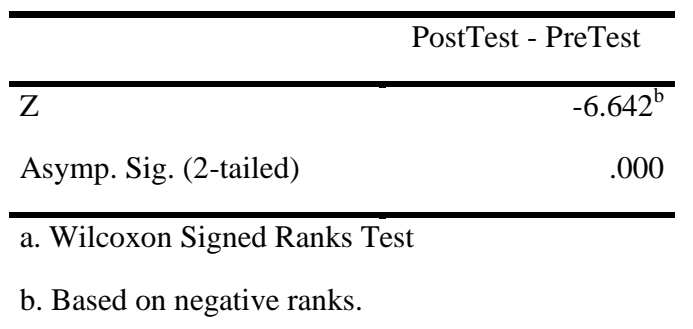

Source: Data Olahan SPSS, 2020

Based on the results of the Wilcoxon Signed Rank Test above, it is known that Asymp. The sign is 0.000 less than alpha 0.05 , which means that $\mathrm{H} 0$ is rejected and $\mathrm{Ha}$ is accepted. It can be concluded that there is a significant difference in scores before and after the hypnoteaching method implemented.

In accordance with the research conducted by Abuhaer (2021) a hypnoteaching can increase student motivation in learning to speak. The results of data analysis show that the t-test value is greater than the t-table value $(5.79>2.1)$ at the significance level $(p)=0.05$. This means that there is a significant difference in speaking skills between the two classes and this indicates that the null hypothesis (H0) is rejected and the alternative hypothesis (H1) is accepted. Therefore, based on the findings and discussion of this 
study, it can be concluded that the application of the Hypnoteaching method improves students' speaking skills.

Another research by Natalia Tri Astuti (2014) who did research in Yadika 4 Junior High School Bekasi. In her study she found that hypnoteaching had a good influence toward the result English vocabulary, different of research area. Based on the research result in this study that is strengthen by some previous result that have been conducted by the other research, the researcher can concluded that hypnoteaching can improve the students achievement not only in reading, or vocabulary but also in speaking, proven by this result that showed that hypnoteaching effective in improving students achievement in speaking.

\section{CONCLUSION}

Based on the results of the research that has been done, there are significant changes before and after the implementation of the hypnoteaching method in learning English where there is an improvement in the value from pre-test to post-test. The researchers hope that the hypnoteaching method can be applied by teachers and lecturers in improving students' English skills. For further researchers, this can be used as capital to develop hypnoteaching method.

\section{REFERENCES}

Abuhaer, H. (2021). Using Hypnoteaching Method to Improve Learning Motivation and Speaking Skill of The Students of SMAN 3 Pangkajene. Qalam: Jurnal Ilmu Kependidikan, 9(2), 66-72.

Astuti, N. T. (2014). Studi eksperimental model pembelajaran hypnoteaching terhadap hasil belajar kosakata belajar bahasa inggris peserta didik. Jurnal Ilmiah Kependidikan, 1(1).

Braun, V., \& Clarke, V. (2006). Using thematic analysis in psychology. Qualitative research in psychology, 3(2), 77-101.

Creswell, J. W., \& Creswell, J. D. (2017). Research design: Qualitative, quantitative, and mixed methods approaches. Sage publications.

Dj, M. Z., \& Sukarnianti, S. (2015). Using Hypnoteaching Strategy to Improve Students' Writing Ability. Dinamika Ilmu: Jurnal Pendidikan, 15(2), 185199.

Flick, U. (2018). Designing qualitative research. Sage.

Hajar, I. (2011). Hypno Teaching: Memaksimalkan Hasil Proses BelajarMengajar dengan Hipnoterapi. Yogyakarta: Diva Press. hypnoteaching strategy to improve students writing ability. Dinamika Ilmu, 15(2), 185-199.

Hamzah B. Uno (2016). Teori Motivasi dan Pengukurnya: Analisa di Bidang Pendidikan. Bandung: PT. Remaja .

Jaya, N. T. (2010). Hypno-Teaching (Bukan Sekedar Mengajar). Bekasi: DBrain. 
Noer, M. (2010). Hypnoteaching for success learning. Yogyakarta: Pedagogia.

Oliver, D. G., Serovich, J. M., \& Mason, T. L. (2005). Constraints and opportunities with interview transcription: Towards reflection in qualitative research. Social forces, 84(2), 1273-1289.

Puspitasari, W. D. (2018). Implementasi Metode Hypnoteaching untuk Meningkatkan Hasil Belajar Siswa Sekolah Dasar. Jurnal Cakrawala Pendas, 4(1).

Sardiman, A. M. (2000). Interaksi \& motivasi belajar mengajar. PT RajaGrafindo Persada.

Setiawan, B. A. (2018). Pengaruh Metode Hypnoteaching Terhadap Aktifitas Belajar Dan Dampaknya Terhadap Hasil Belajar Siswa Kelas Vii Pada Mata Pelajaran Al-Islam Di Smp Muhammadiyah 1 Jember. TARLIM: JURNAL PENDIDIKAN AGAMA ISLAM, 1(1).

Sugiyono, S. (2010). Metode penelitian kuantitatif dan kualitatif dan R\&D.

Yustisia, N. (2012). Hypnoteaching: seni ajar mengeksplorasi otak peserta didik. Yogyakarta: Ar-Ruzz Media. 